\title{
OTTOMAN TENT FROM PRINCE CZARTORYSKI'S COLLECTION - A NEW LOOK AT AN OLD TRADITION
}

7 he memories of relationships between Poland and Turkey has become a source of some deeply entrenched myths. Notoriously persistent among them, was a belief in the incredibly rich spoils gained after the victorious battles of Polish warriors at Chocim in 1621 and 1673, Zurawno in 1676 and, most important of all, during the Vienna campaign and final victory. This belief was so prevalent that provenance from war trophies was attributed to nearly every piece of Turkish art in Polish collections. Undoubtedly, some exquisite specimens of Turkish art in Poland have been acquired in that way, as has been confirmed by sources and stylistic analyses. However, some other items were added to this group later, with the intent of embellishing tradition. The lack of evidence to support any alleged connection with war spoils and contradictory stylistic features was blithely concealed.

The tent in the Czartoryski Princes' collection, at first sight clearly differs from other known Turkish tents, including those stored in the Wawel Royal Castle Museum in Kraków. It is now marked with the symbol XIV-892, though in earlier inventories, especially that made by Bentkowski in 1880, it was given the number 823 and was described as "a Turkish tent of woollen cloth, embroidered." In the earliest studies, first of all in those by Stanisław Gąsiorowski, the inventory number refers to this item. ${ }^{2)}$

Those authors who wrote about this tent, were practically unanimous in attributing it to the trophies from the battle of Vienna. Only T. Mańkowski

\footnotetext{
1) The Princes Czartoryski Library, no 12773.

2) The Princes Czartoryski Library, no 13174.
} 
departed from this trend by describing this object in 1954, first and foremost, as a work of art: "a tent of the garden type, decorated in bright colours, mainly blue, showing advanced decay of the mihrab ornamentation and a loss of the consciousness of its original meaning. This type of its decoration may suggest the influence of Persian embroidery, produced at that time at Resht. The large rounded medallions and their fragments in the tent's roof point to a Turkish or Anatolian, rather than Persian, manner of treating the ornament". ${ }^{3)}$ The traditional attribution was also questioned in 1966 by M. Rychlewska, who dated the tent to the turn of the 18th century, as if she had not noticed the tradition attached to the tent that made it part of the Vienna trophies. ${ }^{4)}$ St. Komornicki considered the tent to be one that had been won at Vienna. ${ }^{5}$ St. Gąsiorowski tried to justify this romantic vision of the tent's origin in the paper La tente orientale $d u$ Musee Czartoryski a Cracovie. $\left.{ }^{6}\right)$ He tried to explain the fact that the tent had not been listed in an inventory of the Gothic House in Pulawy in 1828, by associating the tent with records in an inventory of chattels in the palace in Puławy in 1781. This inventory included various tents but none of the records refer to the tent discussed herein. Similarly, the tent was not shown among the antiquities from Hotel Lambert in Paris, presented at the exposition held in the Polish Hall of Trocadero Palace and was not included in the catalogue of this exposition. Professor Z. Żygulski, an advocate of the romantic tradition, in a catalogue of an exposition devoted to the relief of Vienna published in 1990, dated the tent to the second-half of the 17 th century and recognized it as a high-class ceremonial tent, according to tradition a trophy from the Battle of Vienna. ${ }^{7)}$

The tent was subject to restorative work before the exposition, between 1977 and 1983, in the textile conservation laboratory of the National Museum in Kraków. The work was completed by a team led by Jadwiga Faust. A short report concerning the conservation work and a stylistic analysis were published in a brief paper. ${ }^{8)}$ This included a suggestion that at least part of the tent dates from the 18th century. A few years later, Professor N. Atasoy ${ }^{9}$, who
3) Mańkowski (1954: 153).
4) Rychlewska (1966: 535, il.223-227).
5) Komornicki (1929).
6) Gąsiorowski (1959: 303-321).
7) Kraków 1983 (1990: kat.nr 640).
8) B. Biedrońska-Słota (1980 : 276-279).
9) N. Atasoy, The Ottoman Imperial Tent Complex, Istanbul 2000. 
dated the tent from the Czartoryski Princes' collection at the turn of the 19th century, presented a similar conclusion.

The tent has three walls: the back wall, ca. $180 \mathrm{~cm}$ tall, and two side walls, in the form of irregular quadrilaterals, up to $260 \mathrm{~cm}$ tall at the front. The irregular form of each side wall was obtained by adding three triangles, sewn along the upper edge of each side wall, to the basic rectangle and along the vertical periphery of the side walls, in such a way that a bigger (taller) triangle was added at the front and a smaller (lower) one at the back, adjusting the height to the height of the tent's back wall (Fig. 1). The added triangles differ in their material from the walls and the roof (Fig. 2). The walls and the roof are made from thin woollen cloth with appliqué of woollen cloth (Fig.3). Depending on the complexity of a given element of the pattern, the appliqués are one- or multi-layered, multi-coloured, in orange, pink, carmine and hues of blue and green. Every element of the pattern has been outlined with a silk cord. The triangles mentioned, added at the front and back and along the upper margins of the side walls, are made from woollen cloth by 'incrustation': that is by sewing coloured cloth, then adding the pattern into the background cloth. The selvedges of the pattern are outlined with lay silk cord as described above.

It should be noted that, besides the three walls, a fourth one was added at the front; though it looks like a wall, its function is different. It is raised like a canopy so as to achieve a ceremonial effect. The tent is covered on the exterior with impregnated canvas and after unfolding, it was supported by four wooden poles with brass knobs on top.

The borders of the roof and the lower borders of the three walls are trimmed on the outer side with a cotton band decorated with an ornament of interrelated lilies, known as medachyl. Inside the tent, the cotton band is placed along the upper border, along the roof edges; it is made of woollen cloth, with a motif of a twig with flowers.

The parts of the tent that have been described are permanently sewn together, at odds with the traditional concept of a tent consisting of separate parts assembled according to classical rules of construction. The treatment of the fourth, frontal wall also departs from traditional construction; this wall is raised in a canopy-like manner, with its added triangles spread laterally. From the point of view of the construction and function of its elements, the triangles are superfluous; they may even suggest a lack of comprehension of the tent's functions on the part of its creators, even if it was designed for ceremonial occasions only, as seems to be the case. 
Only a few specimens of tents designed in a similar way, with a raised roof, known as sayeban marquée, are preserved worldwide. The earliest of them, and in fact the only one with a raised canopy, is held in the collection of the Historical Museum in Berlin. It is circular in plan, with a great canopy in front. It has been made in the traditional manner by appliqué on canvas. Such tents are presented on Turkish miniatures from the end of the 18th and 19th century, preserved in the Topkap1 collection. A couple of tents from much later times, from the end of the 18th and 19th century, stored in the Army Museum in Istanbul (Fig. 4), are similar in construction to the tent from the Czartoryski Princes' collection. The side walls are shaped in a similar way, by adding triangles sewn along the upper borders of the side walls and by adding triangles at the front; a canopy in front was suspended in a like manner. The Museum also has separate sayeban canopies that were appended in front of the tents to give them a ceremonial look. One marquée tent in particular, belonging to Sultan Mahmud II (1808-1839), is almost identical to the tent from the Princes Czartoryski Princes' collection in construction, decoration and details of ornament. Dimming has noted this recently, stressing the ceremonial nature of the marquee. ${ }^{10)}$

A tent held in the Victoria \& Albert museum collection, whose description was published by Baker, described as a shah's tent from the times of the Quajar dynasty, from the beginning of the 19th century, is also noteworthy ${ }^{11)}$ The tent resembles that from Kraków in its shape and proportions: $5.28 \mathrm{~m}$ long, $2.70 \mathrm{~m}$ high and $220 \mathrm{~cm}$ wide.

According to P. Baker's attribution, the tent was produced in Resht, the town mentioned by Mańkowski. Resht lies on the southern shore of the Caspian Sea and it became famous during the times of Persian rule for the floral embroidery made there. The embroidery or patchwork on wide pieces of woollen cloth were made in various colours; seams or pieces were covered with embroidery that also varied in colour. A similar technique known as 'incrustation' was also used to produce decorated textiles in Karadah, Isfahan and Shiraz. Indeed, if we follow Mańkowski's suggestion, the tent in the Victoria \& Albert museum is similar to the one discussed herein, but somehow different. The one from London consists of separate parts, the motifs of the design are treated in a different way; they include birds and animals, and even human figures - completely absent in the decoration of the tent from

\footnotetext{
10) Dimmig (2014: 341-372).

11) Baker (1995: 138-139).
} 
Krakow. This omission may easily be explained, if we accept that the inspiration came from the tent from Resht, by the fact that representation of human and animal figures was avoided in Islamic art for religious reasons. The rules adopted from Islamic tradition were applied less rigorously in Persian art, partly because of the acceptance of the Shiite version of Islam.

The tent from Kraków is decorated with mihrabs: four on each side wall, three on the back wall and three on the canopy. The mihrabs are filled with niches roofed by horseshoe arches. Slim cypress trees are placed on both sides of every niche in two plans: the taller ones in front and those behind them presented as lower or above. Every mihrab field is axially filled with a branching bouquet growing from a jug. The individual mihrabs differ only in the details of their design: in the central mihrab on the back wall, small houses with crescents on roofs replace the small cypress trees present in the other mihrabs below the column bases. The side mihrabs on the back wall have a slightly different, more dynamic design. Their horseshoe arches are narrower than the distances between the columns. The columns are decorated with a peacock eye motif and are placed on stepped bases; the bouquets are placed in chalices of complex forms. Small pavilions treated decoratively and cypress trees are placed on the sides of the chalices.

A textile held in the collection of the Sadberk Hanm Museum in Istanbul, $588 \times 162 \mathrm{~cm}$ in size and decorated by appliqué technique with embroidery (labelled SHM 12448 - İ.1284), looks as if it had been made in the same workshop at the same time as the tent from the Czartoryski Princes' collection, taking into consideration the whole composition, the design of individual motifs and their details, colours, material and technique (Fig. 5). The embroidery has been dated by the authors of a recently published catalogue of the Sadberk Hanim Museum to the beginning of the 19th century, ${ }^{12)}$ and it was made in Banja Luka. Each of the seven niches in the piece from Sadmerk Hanim has appliqué in different colours and they also vary in the details of their design. A characteristic feature of these appliqués is the peculiar richness of their palette of colours, with a great variety of hues and shades of colour. Each niche is framed by a band with continuous ornamentation on a dark pink background and is filled with a mihrab enclosed by a horseshoe arch supported by columns with bases. Variously shaped vases with flowers and fruits are placed centrally in every niche. A band with a floral composition along the lower and the upper border flanks the whole.

12) Hulya Bilgi - Idil Zanbah (2012, cat. no. 46: 51, 158). 
Banja Luka lies at Bosnia, which was incorporated into the Ottoman Empire in 1527. The town was famous for its numerous artisans, mainly embroiders. The favourite technique of textile decoration in Banja Luka was the technique of appliqué, consisting of attaching adequately cut textile fragments in various colours to the background cloth. This technique was commonly used in the 19th century to create tapestries with a representation of a mihrab niche, used for prayers. Their composition reveals the clear influence of European art, a natural consequence of the location of the town and of its history, as described by Bilgi - Hülya - Zanbak İdil. As for its material, the styling of its motifs, the whole composition and its details; the tapestry could fit perfectly into the tent from the Princes Czartoryski Princes' collection as an integral part.

The roof of the tent in the Sadberk Hanm Museum has been made technically in the same manner as the side walls. Its composition is typical for Turkish art and is used in decoration of carpets, tapestries and even book covers: a central rosette with fragments of the rosette in the corners. Similar tent roofs may be found in the Army Museum and they belong to the most distinctive tent compositions made in Istanbul at the beginning of the 19th century.

The triangles sewn in and added at the borders of the side walls are made using the technique of 'incrustation'. A tapestry from the collection of The Badischen Landesmuseum in Karlsruhe, described by Veronike Gervers ${ }^{13)}$ as an example of the influence of Turkish art in Eastern Europe, was made from woollen cloth using the same technique and in similar colours (Fig. 6). The author dated the tapestry to the 17th century. Gervers, and after her the authors of the respective entry in the inventory published in Karlsruhe, describe this textile as kelevet, a tapestry made of English woollen cloth using a mosaique technique in Transylvania, in the zone of European influence. ${ }^{14)}$ The triangular fragments of the tent were most likely cut from a similar, but much larger, tapestry made near the end of the 18th century, as is shown by its large size and by the sketchy treatment of details.

Thus, the tent's construction is indicative of its ceremonial function, much like the above mentioned marquee from the Army Museum in Istanbul, and bearing a striking similarity to the appliqué from Banja Luka; both indicate

13) Garvers (1982).

14) Die Karlsruhe Turkenbeute (1991: kat. nr 283). 
that the tent of the sayeban type, designed for ceremonial use, was made at the beginning of the 19th century.

Notwithstanding the above, Prince Władysław Czartoryski bought this tent, believing it to have been captured during the Battle of Vienna, and this romantic vision had lasted so charmingly until, by pure chance, analogies appeared which contradict this romanticised tradition.

\section{BIBLIOGRAPHY}

Atasoy (2000) = Atasoy, Nurhan, The Ottoman Imperial Tent Complex, Istanbul 2000.

Baker (1995) = Baker, Patricia L., Islamic Textiles, London 1995, 138-139.

Biedrońska-Słota $(1980)=$ Biedrońska-Słota, Beata, Conservation of the 17th Century Oriental Tent from the Czartoryski Collection in Cracow, in: Conservazione e restauro dei tessili, Francesco Pertegato (ed.), Como 1980: 276-279.

Bilgi (2012) = Bilgi Hulya-Zanbah Idil, Ottoman Embroideries in the Sadberk Hanim Museum Collection, Istanbul 2012, cat. no. 46, 51, 158.

Dimming $(2014)=$ Dimmig, Ashley, Fabricating a New Image: Imperial Tents in the Late Ottoman Period, International fournal of Islamic Architecture, vol.3, no 2, 2014: $341-372$.

Garvers (1982) = Garvers, Veronica, The influence of Ottoman Turkish textiles and costume in Eastern Europe : with particular reference to Hungary, Royal Ontario Museum 1982.

Karlsruhe $(1991)=$ Die Karlsruhe Turkenbeute. Die „Turckische Kammer” des Markgrafen Ludwig Wilhelm von Baden-Baden, München 1991, cat. no 283.

Komornicki (1929) = Komornicki, Stanisław, Muzeum Książąt Czartoryskich w Krakowie, Kraków 1929.

Kraków (1983) = Odsiecz wiedeńska 1683. Wystawa jubileuszowa $w$ Zamku Królewskim na Wawelu w trzechsetlecie bitwy. Tło historyczne i materiaty źródtowe, t. I, Kraków 1990 , cat. no 640.

Mańkowski (1954) = Mańkowski, Tadeusz, Polskie tkaniny i hafty XVI-XVIII wieku, Wrocław 1954.

Rychlewska (1966) = Rychlewska, Maria, Namiotnictwo, in: Zarys historii wtókiennictwa na ziemiach polskich, Janina Kamińska, Irena Turnau (ed.), Wrocław 1966.

Gąsiorowski, Stanisław, La tente orientale du Musee Czartoryski a Cracovie, Folia Orientalia I, 2, Kraków 1959. 


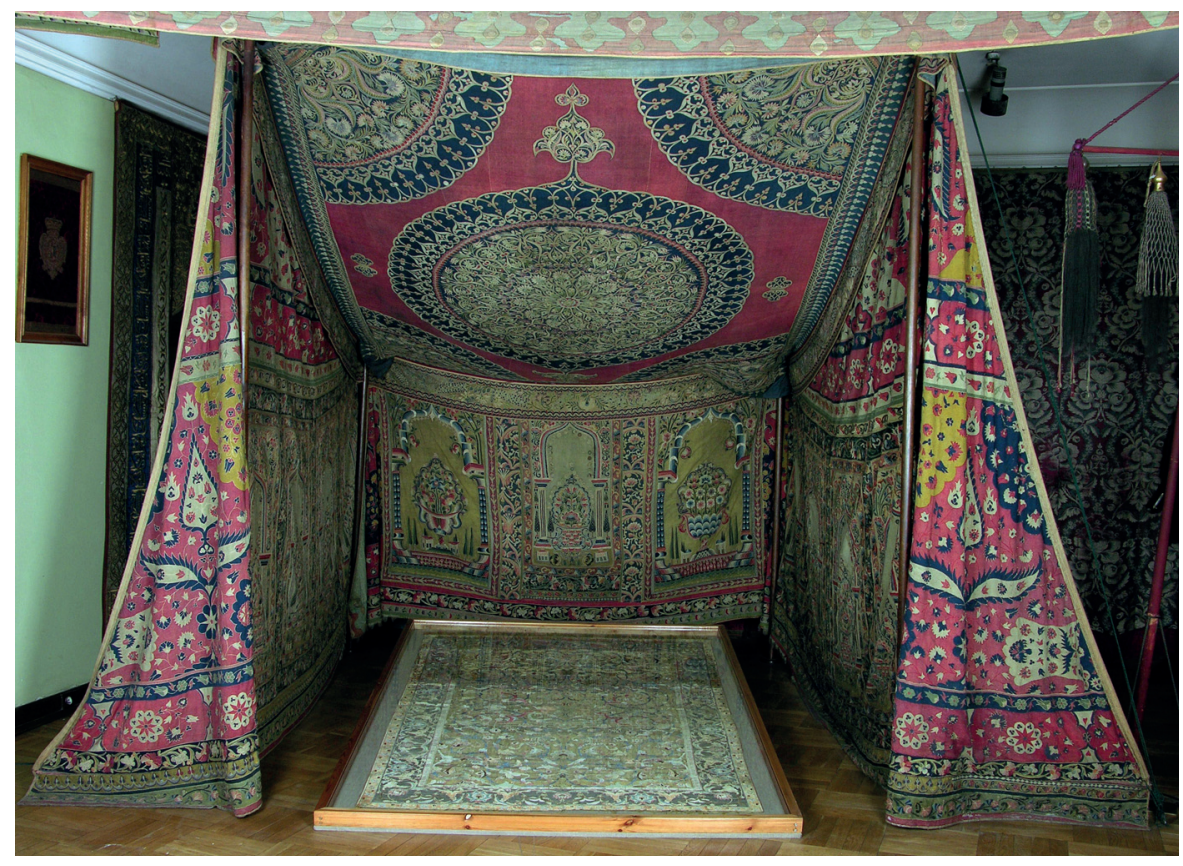

Fig. 1. The tent from XX. Czartoryski Collection, photo: National Museum in Krakow

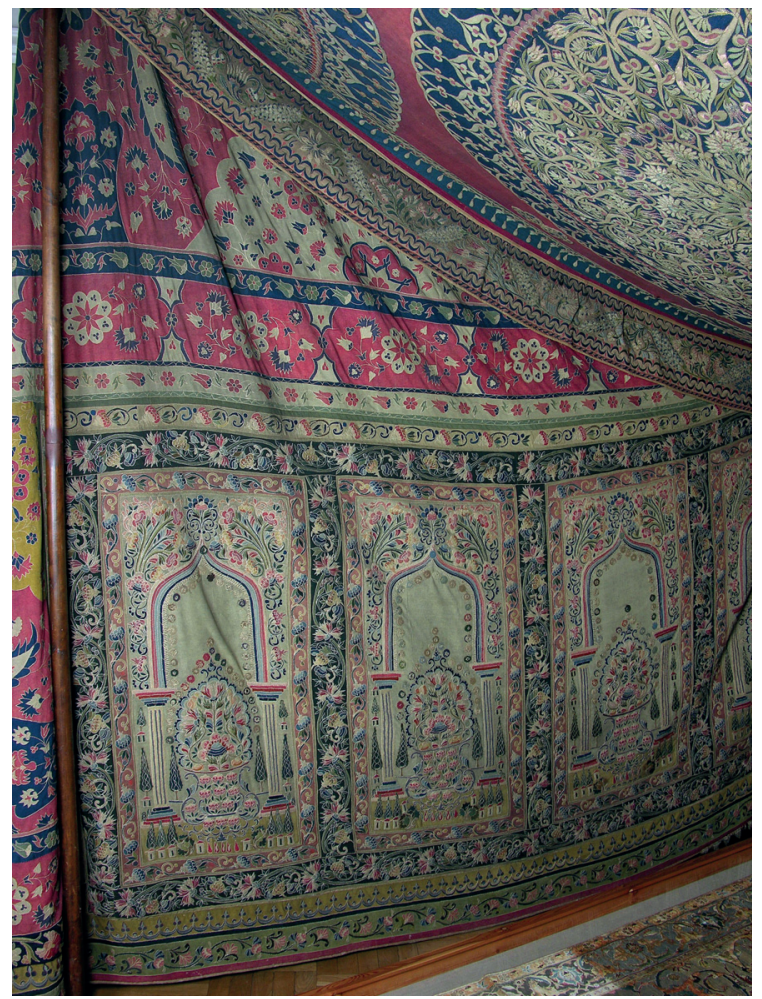

Fig. 2. The added triangles fragment of the tent from XX. Czartoryski collection, photo: National Museum in Krakow 


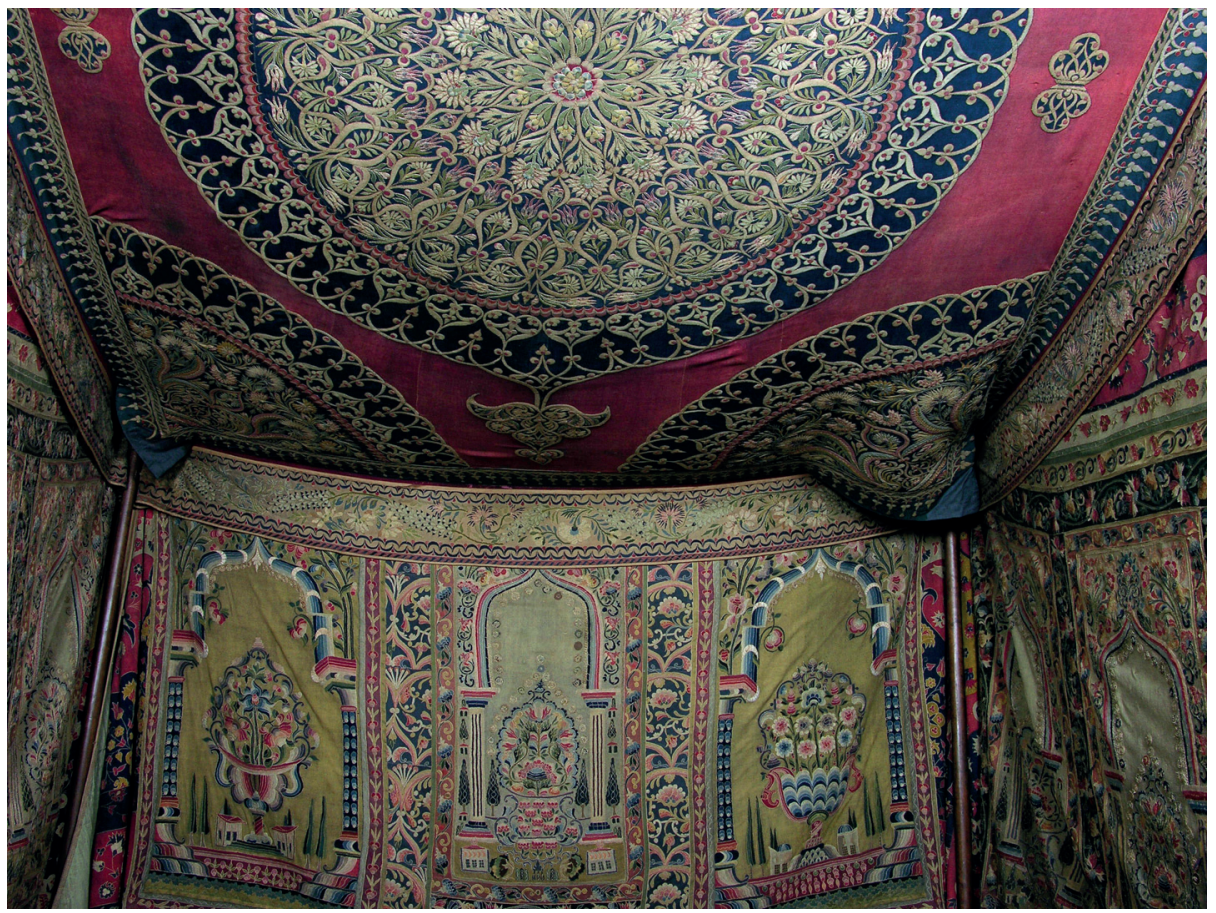

Fig. 3. The walls of the tent from XX. Czartoryski Collection, photo: National Museum in Krakow

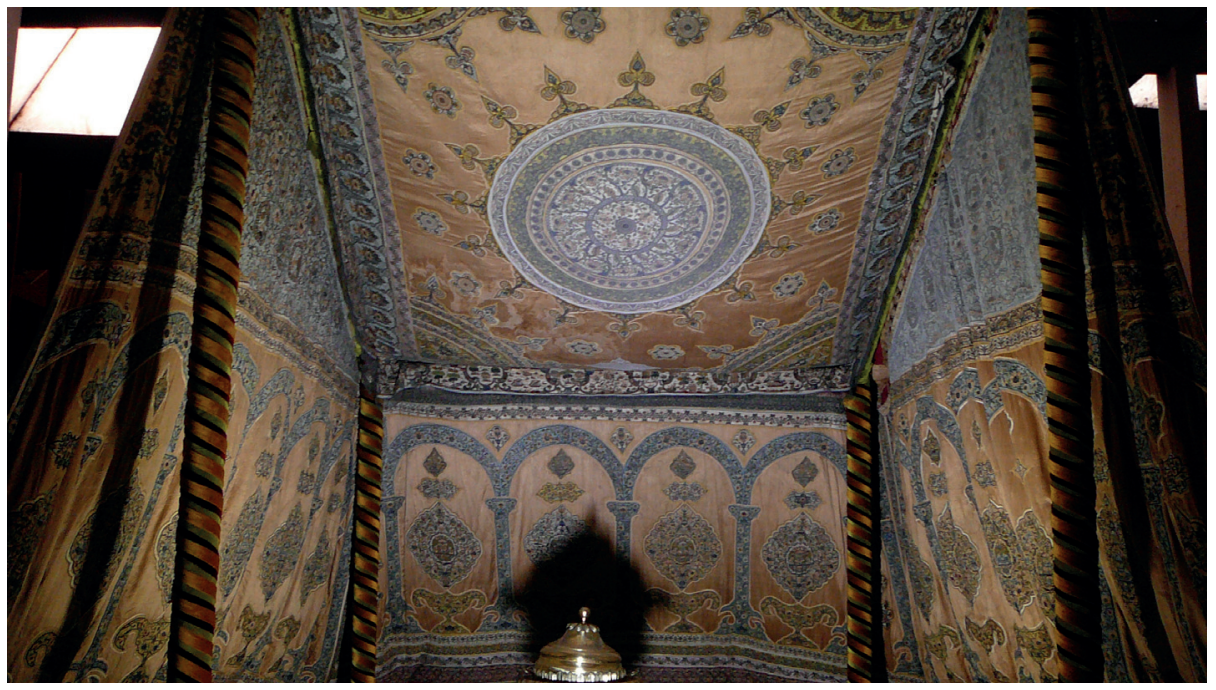

Fig. 4. The tent from Army Museum in Istanbul. Permission from Army Museum, photo: B. Biedrońska-Słotowa 

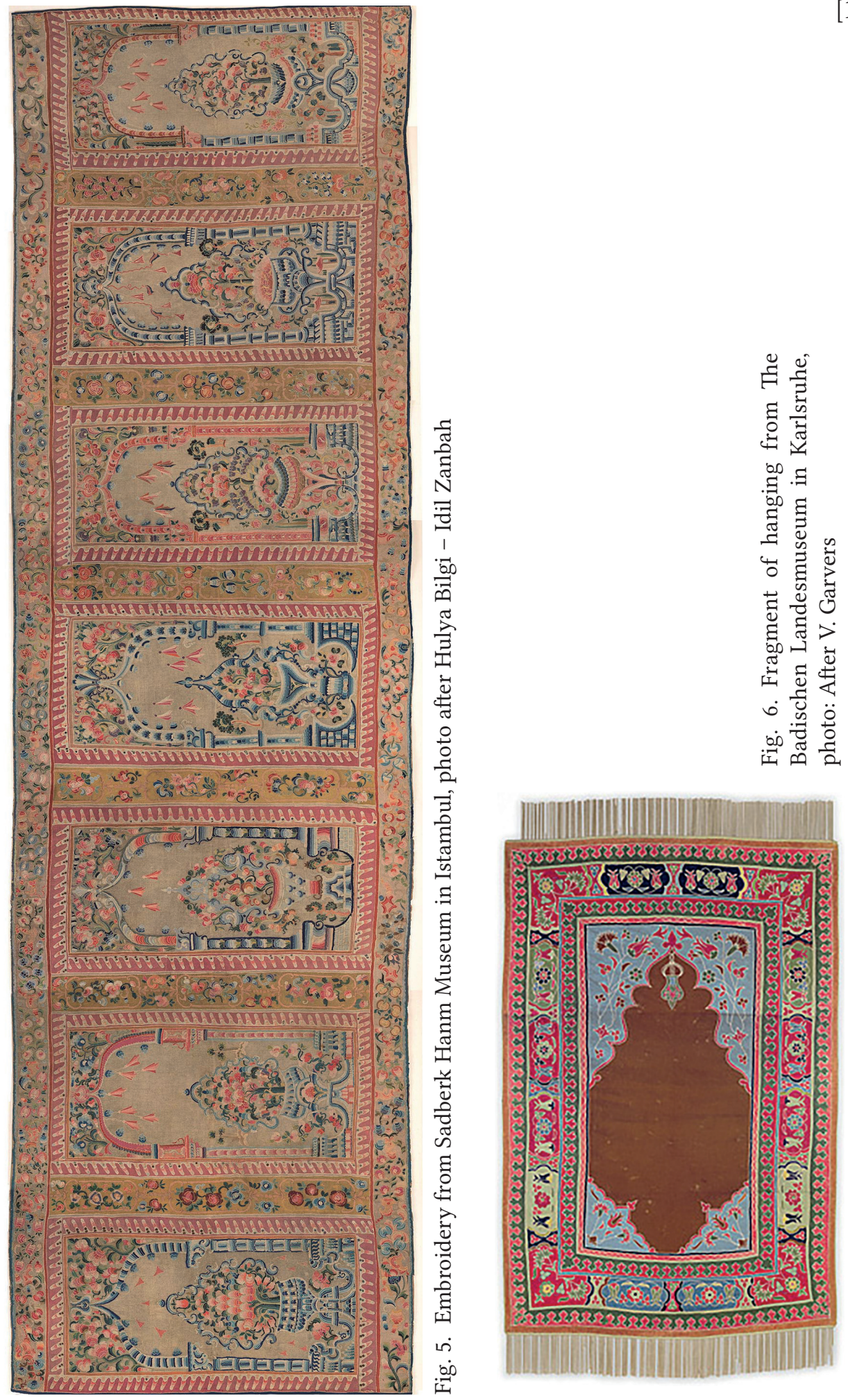

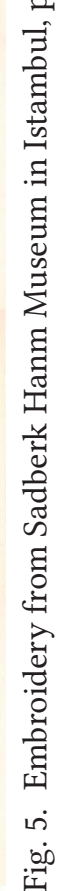

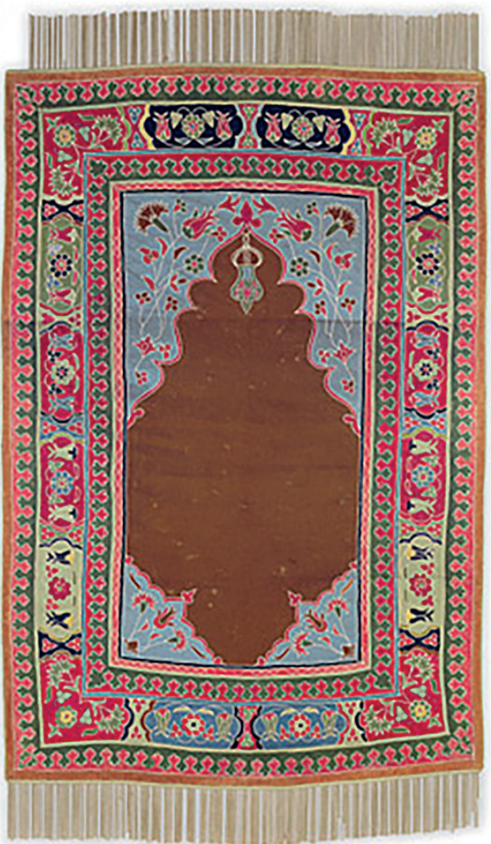

